\title{
PERAN UPAH SEBAGAI MOTIVATOR DALAM MENINGKATKAN PRODUKTIVITAS KERJA KARYAWAN
}

\author{
Oleh: Winda Feriyana ${ }^{1}$, Sri Sarwo Sari' ${ }^{2}$ Yansahrita ${ }^{3}$ \\ (STIE TRISNA NEGARA) \\ ${ }^{1)}$ feriyanawinda@gmail.com ${ }^{2}$ Srisarwosari61@gmail.com, \\ 3)yansahrita82@gmail.com
}

\begin{abstract}
Abstrak
Dalam rangka mempertahankan kelangsungan hidup perusahaan dagang menghadapi persaingan bisnis yang kompetitif saat ini, perusahaan harus dapat dan mampu untuk bersaing. Persaingan yang ketat dilalui jika semua aspek yang dimiliki oleh perusahaan dapat dikelola, dijaga dan dipertahankan tetapi yang terpenting adalah faktor sumber daya manusianya. Perusahaan harus dapat menjaga seluruh sumber daya manusia yang ikut andil dan bekerja diperusahaan. Salah satu alat yang dapat digunakan untuk mengikat para karyawan adalah besarnya upah yang diberikan. Karyawan yang merasa dihargai hasil kerjanya merasa nyaman dalam bekerja dan tercukupi kebutuhannya akan bekerja dengan semangat yang tinggi dan membawa perusahaan pada kemajuan.
\end{abstract}

Kata kunci: Upah, Produktivitas kerja karyawan

\section{ROLE OF WAGES AS A MOTIVATOR IN IMPROVING EMPLOYEE WORK PRODUCTIVITY}

\begin{abstract}
In order to maintain the viability of trading companies facing competitive business competition today, companies must be able and able to compete. Competition is tightly passed if all aspects owned by the company can be managed, maintained and maintained, but the most important is the factor of human resources. Companies must be able to maintain all human resources who contribute and work in the company. One tool that can be used to bind employees is the amount of wages given. Employees who feel valued by their work feel comfortable in working and fulfilled their needs will work with high enthusiasm and bring the company to progress.
\end{abstract}

Keywords: Wage, Employee Work Productivity

PENDAHULUAN

Pada saat ini sumber daya manusia yang bekerja pada suatu perusahan merupakan faktor terpenting dalam membawa perusahaan pada kemajuan. Sumber 
daya manusia memiliki latar belakang pendidikan dan keahlian yang berbeda, kreativitas yang berbeda, bakat pribadi yang berbeda tentu saja memerlukan perhatian dan penghargaan berdasarkan latar belakang masing-masing. Besaran upah yang diterima merupakan salah satu faktor dan alasan dalam seseorang memutuskan untuk bekerja. Karyawan yang merasa dihargai hasil kerjanya akan bekerja dengan sungguh-sungguh dan rela berkorban untuk perusahaannya. Tidak berfikir sedikitpun untuk meninggalkan pekerjaannya atau mencari pendapatan dari tempat lain untuk memenuhi kebutuhan hidupnya. Dan sebaliknya, tenaga kerja yang tidak mendapatkan penghargaan atas kerjanya, tidak mendapatkan imbalan/upah yang sesuai dengan pekerjaannya, lama kelamaan akan berkurang rasa tanggung jawab atas pekerjaanya, bermalas-malasan dan ini semua mengganggu produktivitas kerja karyawan dan lama kelamaan akan membawa perusahaan pada kehancuran.

\section{UPAH DAN NON UPAH}

Upah tidak bersifat sama atau single wage. Ada perbedaan besarnya upah yang dibayarkan kepada pekerja yang muncul karena adanya perbedaan human capital dan perbedaan jenis pekerjaan. Selain upah, banyak perusahaan yang memberlakukan kompensasi non upah atau fringe benefit atau benefit in kind. Kompensasi upah dan non upah ditelaah dalam teori Hedonic. Perbedaan besarnya upah yang disebabkan perbedaan human capital dapat dijelaskan sebagai berikut. Untuk job tertentu, pekerja harus memiliki pendidikan tertentu dan sebagai kompensasinya pekerja yang memiliki penddikan tertentu ini akan memperoleh upah yang tidak sama dengan pekerja yang memiliki pendidikan lainnya.

Dimaksud dengan pekerjaan yang menyenangkan (safe job) adalah pekerjaan yang memiliki status sosial yang tinggi, jam kerja fleksibel, memiliki ruang kerja sendiri dan berlokasi di tempat yang sejuk, nyaman dan aman terhadap resiko. Pekerjaan yang tidak menyenangkan atau pekerjaan yang beresiko (risky job) seperti kondisi 
tempat kerja yang buruk, kerja yang monoton, status sosial yang rendah dan berlokasi di daerah berbahaya dengan resiko tinggi.

\section{KOMPENSASI UPAH}

\section{Perbedaan kompensasi upah berlaku di pasar persaingan tidak sempurna sedangkan pada persaingan sempurna hal ini tidak terjadi. Adanya perbedaan kompensasi di pasar persaingan tidak sempurna karena pekerja dan pekerjaan sifatnya heterogen, sementara di pasar persaingan sempurna diasumsikan pekerja dan pekerjaan homogen.}

Teori kompensasi upah secara esensial menyatakan bagaimana pekerja dan perusahaan "match and mate" dalam pasar kerja. Pekerja adalah orang-orang yang melihat satu set pekerjaan lebih “amenity" dan lazimnya sebagian besar pekerja akan mencari perusahaan seperti ini, sehingga mereka merasa nyaman berada di sana. Perusahaan melihat upah sebagai guide untuk mencapai tingkat efisiensi dari alokasi sumbersumber.

\section{UPAH MINIMUM}

Upah minimum adalah suatu standar minimum yang digunakan oleh para pengusaha atau pelaku industri untuk memberikan upah kepada pekerja di dalam lingkungan usahanya. Upah minimum ditetapkan dengan Peraturan Menteri No.1 Pasal 1 Th 1999. Upah minimum dapat dibagi di atas atau di bawah upah pasar tertentu saja memunculkan konsekuensi yang berbeda. Di satu sisi dapat memunculkan pertambahan jumlah pengangguran, di sisi lain dapat menimbulkan keuntungan berupa efisien ( effisiency wage).

$$
\text { Penetapan upah minimum }
$$
didasarkan pertimbangan: (a) sebagai wujud pelaksanaan UUD 1945, (b) jejaring pengaman agar nilai upah tidak merosot dibawah kebutuhan hidup minimum, (c) upaya pemerataan pendapatan dan proses pertumbuhan kelas menengah. (d) kepastian hukum bagi perlindungan atas hak-hak dasar buruh dan keluarganya sebagai warga negara Indonesia, dan (e) merupakan indikator perkembangan ekonomi pendapatan perkapita. 
Upah minimum ditetapkan melalui Keputusan Gubernur berdasarkan rekomendasi dari Dewan Pengupahan dan berlaku selama 1 tahun berjalan. Karena pemenuhan kebutuhan yang layak disetiap provinsi berbeda-beda maka disebut Upah Minimum Provinsi (UMP).

Upah Minimum di atas dan di bawah Upah Pasar

Sebelum regulasi, pasar berada dalam keseimbangan dengan tingkat upah $\mathrm{W}^{*}$ dan jumlah pekerja $\mathrm{Q}^{*}$ $\left(Q^{\mathrm{S}}=\mathrm{Q}^{\mathrm{d}}\right)$. Jika upah minimum diatas upah pasar maka penetapan upah minimum akan menghasilkan suatu situasi dimana penawaran tenaga kerja akan lebih besar dari permintaan tenaga kerja $\left(Q^{\mathrm{S}}>\mathrm{Q}^{\mathrm{d}}\right)$. Berati terjadi ekses supply $\left(\mathrm{Q}^{\mathrm{s}}-\mathrm{Q}^{\mathrm{d}}\right)$ dan hal ini akan meningkatkan jumlah pengangguran. Jika upah minimum di bawah upah pasar,berarti terjadi ekses demand $\left(Q^{d}-Q^{s}\right)$ permintaan lebih besar dari penawaran tenaga kerja. dengan mekanisme pasar upah minimum akan bergerak naik sehingga mencapai upah pasar.

\section{Upah Efisiensi}

Keuntungan lain upah minimum adalah pekerja memiliki nilai lebih, sebab produktivitas mereka lebih tinggi seperti yang dinyatakan di atas. Untuk meningkatkan produktivitas perlu biaya lebih tinggi. Hal ini membuat biaya pemantauan oleh pengusaha menjadi lebih rendah. Upah menjadi efisien. Dengan biaya pemantauan yang lebih rendah akan membuat perekrutan tenaga kerja akan meningkat.

Menurut Schuler dan Jackson (1999), Mondy, et al. (1999), Schermerhorn, et al. (1998), Robbins (1996), dan Siagian (1995), pada prinsipnya imbalan dapat dibedakan menjadi dua, yaitu imbalan intrinsik dan imbalan ekstrinsik. Imbalan intrinsik yaitu imbalan yang diterima karyawan untuk dirinya sendiri. Biasanya imbalan ini merupakan nilai positif atau rasa puas karyawan terhadap dirinya sendiri karena telah menyelesaikan suatu tugas yang baginya cukup menantang.

Pembahasan dalam tulisan ini akan difokuskan pada imbalan ekstrinsik yang selanjutnya disebut sebagai kompensasi dan diartikan 
sebagai sejumlah uang atau penghargaan yang diberikan oleh suatu organisasi atau perusahaan kepada karyawannya, sebagai imbalan atas jasanya dalam melakukan tugas, kewajiban dan tanggung jawab yang dibebankan kepadanya. Hal ini bukan berarti imbalan intrinsik tidak penting. Menurut Hersey dan Blanchard (1995), bagi kelompok karyawan yang telah memiliki jaminan kebutuhan fisiologis dan rasa aman, maka imbalan intrinsik guna meningkatkan harga dirinya menjadi motivasi utama dalam bekerja. Berikut ini akan dibahas tentang kompensasi total, tujuan kompensasi, dasar perhitungan kompensasi, kepuasan terhadap kompensasi dan hubungan kompensasi dengan peningkatan kinerja karyawan.

\section{MOTIVASI}

Keseluruhan proses pemberian motivasi bekerja kepada bawahan sedemikian rupa sehingga mereka mau bekerja dengan ikhlas demi tercapainya tujuan organisasi dengan efisien dan ekonomis. Kekuatan kecenderungan seorang individu melibatkan diri sebagai motivator yang berarahkan kepada sasaran dalam pekerjaan, ini bukan perasaan senang yang relatif terhadap hasil pekerjaan seperti halnya kepuasan tetapi lebih mengarah kepada perasaan sedia / rela bekerja untuk mencapai tujuan dari pekerjaan tersebut. menurut malayu SP. Hasibuan: 2002, motivasi adalah "Daya penggerak yang menciptakan kegairahan kerja seseorang agar mau bekerja sama, bekerja efektif dan terintegrasi dengan segala daya upaya untuk mencapai kepuasan".

\section{KOMPENSASI TOTAL}

Menurut Gomez-Mejia, et al., (1995); Schuler dan Jackson (1999); serta Luthans (1998), kompensasi total dapat diklasifikasikan dalam tiga komponen utama, yaitu: Pertama, kompensasi dasar yaitu kompensasi yang jumlahnya dan waktu pembayarannya tetap, seperti upah dan gaji. Kedua, kompensasi variabel merupakan kompensasi yang jumlahnya bervariasi dan atau waktu pembayarannya tidak pasti. Kompensasi variabel ini dirancang 
sebagai penghargaan pada karyawan yang berprestasi baik. Termasuk kompensasi variabel adalah pembayaran insentif pada individu maupun kelompok, gainsharing, bonus, pembagian keuntungan (profit sharing), rencana kepemilikan saham karyawan (employee stock ownership plans) dan stock-option plans. Ketiga, merupakan komponen terakhir dari kompensasi total adalah benefit atau seringkali juga disebut indirect compensation (kompensasi tidak langsung). Termasuk dalam komponen ini adalah perlindungan umum, seperti jaminan sosial, pengangguran dan cacat; (2) perlindungan pribadi dalam bentuk pensiun, tabungan, pesangon tambahan dan asuransi; pembayaran saat tidak bekerja seperti pada waktu mengikuti pelatihan, cuti kerja, sakit, saat liburan, dan acara pribadi; (4) tunjangan siklus hidup dalam bentuk bantuan hukum, perawatan orang tua, perawatan anak, program kesehatan, dan konseling.

Menurut Siagian (1995), rasa keadilan dapat membuat karyawan menjadi puas terhadap kompensasi yang diterimanya. Sebaliknya, pihak perusahaan juga berharap bahwa kepuasan yang dirasakan oleh karyawan akan mampu memotivasi karyawan tersebut untuk meningkatkan kinerjanya, sehingga tujuan perusahaan dapat tercapai. Apabila hal ini dapat terwujud, sebenarnya bukan hanya tujuan perusahaan yang tercapai, namun kebutuhan karyawan juga akan terpenuhi.

\section{TUJUAN KOMPENSASI}

Menurut Schuler dan Jackson (1999) kompensasi dapat digunakan untuk (a) menarik orang-orang yang potensial atau berkualitas untuk bergabung dengan perusahaan. Dalam hubungannya dengan upaya rekrutmen, program kompensasi yang baik dapat membantu untuk mendapatkan orang yang potensial atau berkualitas sesuai dengan yang dibutuhkan oleh perusahaan.

Tujuan dari pemberian kompensasi tersebut saling terkait, artinya apabila pemberian kompensasi tersebut mampu mengundang orang-orang yang potensial untuk bergabung dengan perusahaan dan membuat karyawan 
yang baik untuk tetap bertahan di perusahaan, serta mampu memotivasi karyawan untuk meningkatkan kinerjanya, berarti produktivitas juga akan meningkat dan perusahaan dapat menghasilkan produk dengan harga yang kompetitif, sehingga perusahaan lebih dimungkinkan untuk dapat mencapai sasaran strategisnya yaitu mempertahankan kelangsungan hidup dan mengembangkan usaha.

\section{Upah dan Upah Minimum}

Para pengusaha selalu berusaha mendapatkan keuntungan sebesar-besarnya dengan menekan biaya berupa upah dan gaji seminimal mungkin karena faktor upah dan gaji merupakan faktor biaya bagi pengusaha

Pemberian upah dipengaruhi oleh masalah persaingan di pasar tenaga kerja, pendidikan, keterampilan, perilaku karyawan dan pengalamannya. Penetapan upah juga melihat kepada tingkat produktivitas, biaya hidup dan laba yang diperoleh pengusaha, ini semua dikemukakan oleh Buchari Alma (2002). Demikian juga halnya yang dinyatakan oleh
Bruce E. Kaufman dan Julit L. Hotchkins (2003) : "Wage Rate is Infinitive Obvious it is the Price of Labour per Hour of Work". Sedangkan dalam teori ekonomi menurut Sadono Sukirno (2004) upah didefinisikan sebagai pembayaran yagn diperoleh beri berbagai bentuk jasa yang disediakan dan diberikan oleh tanaga kerja kepada para pengusaha.

\section{A. Jenis Upah}

1. Upah Uang Diartikan sebagai jumlah uang yang diterima para pekerja dari para pengusaha sebagai pembayaran atas tenaga mental atau fisik para pekerja yang digunakan dalam proses produksi, Sadono Sukirno(2004).

2. Upah Rill Adalah tingkat upah pekerja yang diukur dari sudut kemampuan upah tersebut untuk membeli barang-barang dan jasa-jasa yang diperlukan untuk memenuhi kebutuhan para pekerja.

\section{B. Upah Minimum}


Upah minimum adalah suatu standar minimum yang digunakan oleh para pengusaha atau pelaku industri untuk memberikan upah kepada pekerja di dalam lingkungan usahanya (Nurlina Tarmizi, 2012).

Upah minimum yang ditetapkan berdasarkan peraturan menteri No.1 Pasal 1 Ayat 1 Th 1999 yaitu "Upah minimum dapat diatas atau dibawah upah pasar". Tentu saja hal ini meunculkan konsekuensi yang berbeda. Disatu sisi dapat memunculkan pertambahan jumlah pengangguran, di sisi lain dapat menimbulkan keuntungan berupa upah efisien (Efficience Wage).

\section{KESIMPULAN}

Banyak faktor yang mempengaruhi produktivitas kerja diantaranya, pemberian upah yang layak, motivasi, tingkat pendidikan, disiplin, latihan keterampilan dan sebagainya. Faktor tersebut mempunyai peranan yang sangat penting dalam peningkatan produktivitas kerja untuk mencapai tujuan perusahaan.

Pemberian upah yang berdasarkan pada upah minimum yang sudah diukur dengan layak dan tepat akan menimbulkan hubungan yang baik, antara karyawan dan perusahaan sehinggaa terciptanya suasana kerja tentram ditempat kerja, sebab dengan demikian karyawan akan merasa tenang dalam bekerja dan tentunya produktivitas meningkat seiring dengan tercapainya tujuan perusahaan atau organisasi.

\section{DAFTAR PUSTAKA}

Bruce F. Kaufman, Julit L. Hotckins, 2003, The Economic Of Labour Market, South Western: Thomson

Hasibuan, Malayu. S.P. 2000. Manajemen Sumber Daya Manusia. Edisi revisi.. Jakarta : Bumi Aksara.

Nurlina. Tarmizi, 2012, Ekonomi Ketenagakerjaan,Edisi Kedua, Palembang UNSRI Press

Sadono. Sukirno, 2000, Pendidikan Makro Ekonomi, Edisi Kedua, Jakarta : PT. Raja Grafindo

Sadono. Sukirno, 2004, Pendidikan Teori Mikro Ekonomi, Edisi Ketiga, Jakarta : PT. Raja Grafindo Persada

Schuler, R. S dan SE. Jackson, 1999, Manajemen SDM-Menghadapi Abad ke-21, Jilid 2, Jakarta : Erlangga

Sedarmayanti, 2013, Manajemen Sumber Daya Manusia, Cetakan Ke enam, Bandung : PT. Refika Aditama

http://sobatbaru.blogspot.com/2010/0 5/pengertian-upah.html 